\title{
Assessment of Voiding Dysfunction and Nocturnal Enuresis Rates in Primary School Children in an Anatolian City with a Validated Dysfunctional Voiding Scoring System Questionnaire
}

\author{
Bir Anadolu Şehrinde Valide Edilmiş Işeme Sorgulama Sistemi ile Illkokul Çağı \\ Çocuklarındaki Işeme Bozuklukları ve Enürezis Oranının Belirlenmesi
}

\author{
(D) Hasan Hüseyin Tavukçu1, (D) Yılören Tanıdır², (D) Esra Tavukçu3, (D) Cem Akbal2, (D) Ferruh Şimşek², (D) Tufan Tarcan² \\ 1Istanbul Bilim University, Istanbul Florence Nightingale Hospital, Clinic of Urology, İstanbul, Turkiye \\ 2 Marmara University Faculty of Medicine, Department of Urology, Istanbul, Turkiye \\ 3istanbul Bilim University, Vocational School of Health Services, İstanbul, Turkiye
}

What's known on the subject? and What does the study add?

Voiding dysfunction is a common problem in children which may affect families and children in terms of psychology, behaviour and financial burdens. There is no data about the prevalence of voiding dysfunction in many cities of our country. In this study, we investigated the prevalence of voiding dysfunction as well as related factors among primary school children in Karaman city using a validated dysfunctional voiding scoring system.

\begin{abstract}
Objective: To investigate the prevalence of voiding dysfunction (VD) and nocturnal enuresis (NE) in Turkish primary school children using a previously validated Dysfunctional Voiding Scoring System (DVSS) questionnaire and a self-administered questionnaire.

Materials and Methods: The previously validated DVSS questionnaire was completed by the parents of 3015 randomly selected children. Another questionnaire was also administered for studying VD and NE rates, demographic characteristics, and learning or behavioral problems of children.

Results: Of all children, 6.6\% ( $n=199)$ had a score suggesting VD and 6.1\% ( $n=185)$ had NE. No significant differences were found between children with and without VD in terms of age, gender, and fluid intake. Children with VD had significantly high rates of constipation (19.7\% vs 5.2\%; $\mathrm{p}<0.001)$ and fecal soiling $(32.1 \%$ vs $5.1 \% ; \mathrm{p}<0.01)$ compared with children without VD. Children with a higher DVSS score had more frequent behavioral or psychological problems $(20.7 \%$ vs $4.7 \% ; p<0.01)$ and learning disabilities $(14.7 \%$ vs $5.5 \%$; $p<0.01)$. VD had no correlation with overall maternal education level and the type of school (government or private).

Conclusion: VD and NE are highly frequent in early childhood and positively correlated with children's learning disabilities and psychological problems.

Keywords: Pediatric, Primary school, Symptom score, Voiding dysfunction

$\ddot{0 z z}$

Amaç: Karaman il merkezindeki ilkokul çağı çocuklarındaki işeme bozukluğu (IB) prevalansının çocukluk çağı İB'leri Semptom Skoru (IBSSS) sorgulama formu ile incelenmesi ve nokturnal enürezisin (NE) belirlenmesi amaçlandı.

Gereç ve Yöntem: İBSS formu, 21 farklı okuldan basit örnekleme ile belirlenmiş 3015 ilkokul çağı çocuğun ebeveynleri tarafından dolduruldu. IBSS 9 ve üzeri İB varlığı olarak temel alındı. Ayrı bir anket formu ile çocukların NE'si, kapsamlı demografik durumları, öğrenme ve davranış bozuklukları sorgulandı.
\end{abstract}

Correspondence: Hasan Hüseyin Tavukçu MD, İstanbul Bilim University, İstanbul Florence Nightingale Hospital, Clinic of Urology, İstanbul, Turkiye Phone: +90 2123756565 E-mail: hhtavukcu@yahoo.com ORCID-ID: orcid.org/0000-0003-0956-7460

Received: 16.12.2017 Accepted: 05.07.2018

Cite this article as: Tavukçu HH, Tanıdır Y, Tavukçu E, Akbal C, Simşek F, Tarcan T. Assessment of Voiding Dysfunction and Nocturnal Enuresis Rates in Primary School Children in an Anatolian City with a Validated Dysfunctional Voiding Scoring System Questionnaire. J Urol Surg 2018;5(4):182-188. 
Bulgular: Çocukların \%6,6'sında İB düşündüren yüksek skor saptanırken, \%6,1'inde NE saptandı. İB olan ve olmayan çocuklar arasında yaş, cinsiyet ve sıvı alımı açısından fark saptanmadı. İB olan çocuklarda anlamlı olarak daha yüksek oranda kabızlık ve iç çamaşırın dışkı ile kirlenmesi raporlandı. İBSS sorgulamasına göre İB düşünülen çocuklarda daha fazla davranış problemleri veya psikolojik problemler ile öğrenme güçlüğü bildirildi. Anne eğitim düzeyi ve okul tipi (devlet veya özel) açısından İB ile korelasyon saptanmadı.

Sonuç: Erken çocukluk döneminde İB ve NE oranı yüksek olup çocukların psikolojik ve öğrenme durumunu negatif olarak etkileyebilmektedir. Anahtar Kelimeler: Çocukluk, illkokul, Semptom skoru, İşeme bozukluğu

\section{Introduction}

Voiding dysfunction (VD) is a common cause for referral to urologists, pediatricians, and pediatric nephrologists. VD may present as urinary incontinence (UI), urinary tract infection (UTI), vesicoureteral reflux, overactive bladder, or constipation.

Nocturnal enuresis (NE), which is $\mathrm{UI}$ at night, affects both children's and parents' social and behavioral attitudes (1). Several classifications have been proposed according to clinical presentations of incontinence symptoms $(2,3)$. Some classification systems are based on clinical presentations, whereas some on urodynamic parameters $(2,4)$. NE is classified as monosymptomatic and non-monosymptomatic. Monosymptomatic NE is UI only at night and without any VD (5). As VD, NE is commonly seen and daytime lower urinary tract symptoms are frequent in children between 5 and 7 years of age; most of whom are primary school children (6).

The prevalence of NE usually varies by region and country. In Turkiye, the prevalence has been reported to be 9-16\% $(7,8,9,10)$. Detection and treatment of NE is of importance due to the high prevalence and the resulting effects on families and children in terms of psychological and behavioral aspects, as well as associated financial burdens.

Distinguishing between monosymptomatic NE and daytime UI as a medical conditions is essential for successful and appropriate treatment $(2,3,4)$. The diagnosis of VD mainly depends on an accurate medical history reported by parents, physical examinations, and urine analysis $(3,11)$. Questionnaires, as a non-invasive method, are useful for diagnosis and in treatment planning and follow-up for VD (3). For an objective diagnosis and treatment follow-up, the Dysfunctional Voiding Scoring System (DVSS), first reported by Farhat et al. (12), provides an exact quantitative tool. Akbal et al. (3) developed and validated the DVSS questionnaire, modified from van Gool et al. (13), for Turkish children. This validated version is commonly used for assessing VD. The use of the DVSS questionnaire in routine clinical practice has risen in recent years (14). In addition to our study, the DVSS questionnaire has been used in some epidemiological studies of Turkish children for detecting the prevalence of VD and UI $(15,16)$.

We investigated the prevalence of VD in children by using the DVSS questionnaire, the associated factors affecting VD, and the prevalence of NE. The sample was drawn from primary school children living in a city in the central Anatolian region of Turkiye.

\section{Materials and Methods}

This was a random-selection based cross-sectional study involving 21 primary schools from March 2012 to May 2012 and employing a self-administered questionnaire and the DVSS questionnaire (Figure 1) (3). The children and parents were not informed about normal voiding and VD before completing the questionnaires. Parental consent and permission from the City Directorate of National Education and National Health were obtained. The DVSS questionnaire was administered to 4.477 parents, whose children were between 7 and 14 years of age. The questionnaires were completed particularly by the mothers and gathered after two weeks.

The first part of the questionnaire included demographic information, including questions on age, gender, school type (government or private), parents' education, family income, number of siblings, any incidence of $\mathrm{NE}$, voiding habits, constipation, fluid intake, and any learning or behavioral problems. The second part was the DVSS questionnaire developed for Turkish children. A score of $\geq 9$ indicated the presence of VD (3).

\section{Statistical Analysis}

The Statistical Package for Social Sciences, version 15.0, for Windows operating system was used to perform statistical analysis. Mean values are given as mean \pm standard deviation. All individual and familial parameters were analyzed for significant risk factors associated with VD. Chi-square test and Student's t-test were performed to assess the differences in children with VD for categorical and continuous variables. A univariate regression analysis was performed to determine the independent factors correlating with VD. A p-value of less than 0.05 was considered statistically significant.

\section{Results}

The study population consisted of 3.015 children with a mean age of $10.2 \pm 2.2$ years (range: $7-14$ years). $6 \%$ (1.387) of subjects were boys and $54 \%$ (1.628) were girls. The response rate was $67.3 \%$. Incomplete questionnaires were not assessed. 


\begin{tabular}{|c|c|c|c|c|}
\hline \multirow{2}{*}{$\begin{array}{l}\text { Does your child have urinary } \\
\text { incontinence (peeing not on } \\
\text { the toilet) during the day? }\end{array}$} & No & Sometimes & $\begin{array}{c}1-2 \\
\text { times/day }\end{array}$ & $\begin{array}{l}3 \text { or more } \\
\text { times/day }\end{array}$ \\
\hline & 0 & 1 & 3 & 5 \\
\hline \multirow[t]{2}{*}{ If yes to Question 2} & A few drops & \multicolumn{2}{|c|}{ Only underwear wet } & $\begin{array}{l}\text { Outer clothing } \\
\text { layers wet }\end{array}$ \\
\hline & 1 & \multicolumn{2}{|c|}{3} & 5 \\
\hline \multirow{2}{*}{$\begin{array}{l}\text { Does your child have urinary } \\
\text { incontinence (peeing not on } \\
\text { the toilet) during the night? }\end{array}$} & No & $\begin{array}{c}1-2 \\
\text { nihgts/week } \\
\end{array}$ & $\begin{array}{c}3-5 \\
\text { nights/week }\end{array}$ & 6-7 nights/week \\
\hline & 0 & 1 & 3 & 5 \\
\hline \multirow[t]{2}{*}{ If yes to Question 4} & \multicolumn{2}{|c|}{ Underwear or pajamas wet } & \multicolumn{2}{|c|}{ Bed wet } \\
\hline & \multicolumn{2}{|c|}{1} & \multicolumn{2}{|r|}{4} \\
\hline \multirow[t]{2}{*}{ My child goes to toilet to pee.. } & \multicolumn{2}{|c|}{ Less than 7 times/day } & \multicolumn{2}{|c|}{7 or more times/day } \\
\hline & \multicolumn{2}{|c|}{0} & \multicolumn{2}{|r|}{1} \\
\hline \multirow[t]{2}{*}{ My child has to strain to pee } & \multicolumn{2}{|c|}{ No } & \multicolumn{2}{|r|}{ Yes } \\
\hline & \multicolumn{2}{|c|}{0} & \multicolumn{2}{|r|}{3} \\
\hline \multirow{2}{*}{$\begin{array}{l}\text { My child experiences pain } \\
\text { when s/he pees }\end{array}$} & \multicolumn{2}{|c|}{ No } & \multicolumn{2}{|r|}{ Yes } \\
\hline & \multicolumn{2}{|c|}{0} & \multicolumn{2}{|r|}{1} \\
\hline \multirow{2}{*}{$\begin{array}{l}\text { My child pees intermittently } \\
\text { when on the toilet }\end{array}$} & \multicolumn{2}{|c|}{ No } & \multicolumn{2}{|r|}{ Yes } \\
\hline & \multicolumn{2}{|c|}{0} & \multicolumn{2}{|r|}{2} \\
\hline \multirow{2}{*}{$\begin{array}{l}\text { My child has to go to revisit to } \\
\text { toilet to pee soon after s/he } \\
\text { pees }\end{array}$} & \multicolumn{2}{|c|}{ No } & & Yes \\
\hline & & & & 2 \\
\hline My child has to run to the & & & & Yes \\
\hline $\begin{array}{l}\text { toilet when } \mathrm{s} / \mathrm{he} \text { feels the need } \\
\text { to pee }\end{array}$ & & & & 1 \\
\hline My child can hold his/her pee & & & & Yes \\
\hline $\begin{array}{l}\text { by crossing his/her legs, } \\
\text { squatting, or doing the "pee } \\
\text { dance". }\end{array}$ & & & & 2 \\
\hline My child wets his/her clothes & & & & Yes \\
\hline before reaching the toilet & & & & 2 \\
\hline My child does not pass stool & & & & Yes \\
\hline every day & & & & 2 \\
\hline & Quali & of life & & \\
\hline If your children experiences & Not at all & Not so much & Affects & Seriously affects \\
\hline $\begin{array}{l}\text { any of the symptoms/issues } \\
\text { mentioned above, does this } \\
\text { affect his/her family life or } \\
\text { social life? }\end{array}$ & 0 & 1 & 3 & 5 \\
\hline
\end{tabular}

Figure 1. The dysfunctional voiding scoring system questionnaire for children

The prevalence of $\mathrm{VD}, \mathrm{NE}$, and monosymptomatic NE was found to be 6.6\% (199), 6.1\% (185), and 2.6\% (78), respectively. The highest incidences of VD (13.1\%), NE (14.5\%), and monosymptomatic NE (5.9\%) were found at age seven years. The frequency of all the three conditions tended to decrease with age (Figure 2 and Table 1).

No statistically significant difference was found in terms of age, gender, or fluid intake between children with and without VD (Figure 3). As per demographic data, we found no significant difference in school type (government or private) or parents' education level but found statistically significant differences in the overall number of siblings $(p=0.040)$ and family income $(p=0.006)$. The subgroup analysis of parents' education level revealed that compared to the children of mothers in other subgroups, children of the university graduate mothers had lower rates of VD ( $p=0.002)$ (Table 2$)$.

The overall rate of constipation was 9.6\% $(n=289)$; the rate was $19.7 \%(n=57)$ in children with VD and was statistically significant $(p<0.001)$. The overall rate of fecal soiling was $5.5 \%$ $(n=165)$; the rate was $26.6 \%(n=53)$ in children with VD and was statistically significant $(p<0.001)$. Children with any congenital
Table 1. The distributions of voiding dysfunction, nocturnal enuresis and monosymptomatic nocturnal enuresis prevalence among age groups in our study

\begin{tabular}{lllll}
\hline $\begin{array}{l}\text { Age } \\
\text { (year) }\end{array}$ & $\mathbf{n}$ & VD \%, (n) & NE \%, (n) & $\begin{array}{l}\text { Monosymptomatic } \\
\text { NE \%, (n) }\end{array}$ \\
\hline 7 & 358 & $13.1(47)$ & $14.5(52)$ & $5.9(21)$ \\
8 & 465 & $10.5(49)$ & $9.9(46)$ & $4.7(22)$ \\
9 & 489 & $9.0(44)$ & $7.8(38)$ & $3.1(15)$ \\
10 & 398 & $7(28)$ & $5.5(22)$ & $1.8(7)$ \\
11 & 412 & $4.4(18)$ & $4.1(17)$ & $2.2(9)$ \\
12 & 369 & $1.4(5)$ & $1.6(6)$ & $0.8(3)$ \\
13 & 307 & $1.3(4)$ & $0.7(2)$ & $0.3(1)$ \\
14 & 217 & $1.8(4)$ & $0.92(2)$ & $0(0)$ \\
Total & 3015 & $6.6(199)$ & $6.1(185)$ & $2.6(78)$ \\
\hline
\end{tabular}

VD: Voiding dysfunction, NE: Nocturnal enuresis

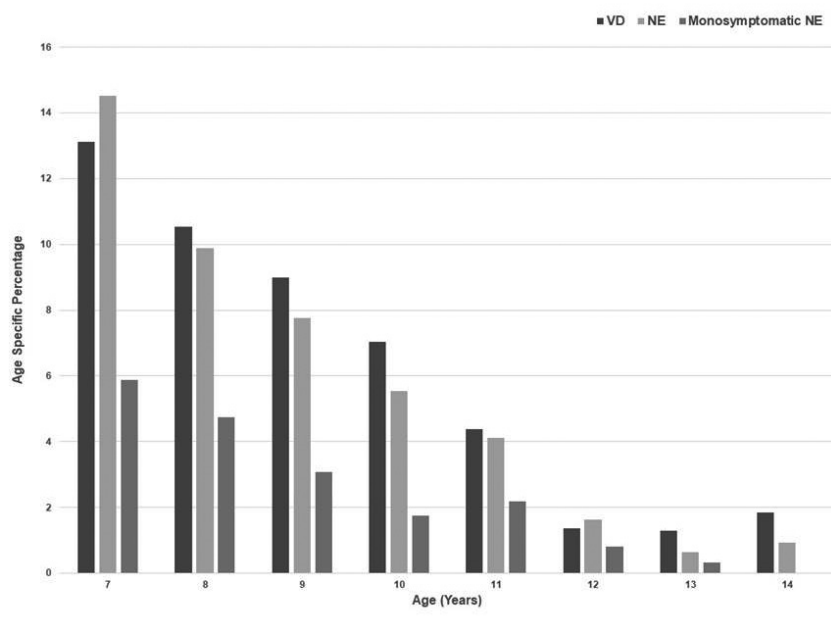

Figure 2. The distributions of voiding dysfunction, nocturnal enuresis and monosymptomatic nocturnal enuresis prevalence among age groups in our study

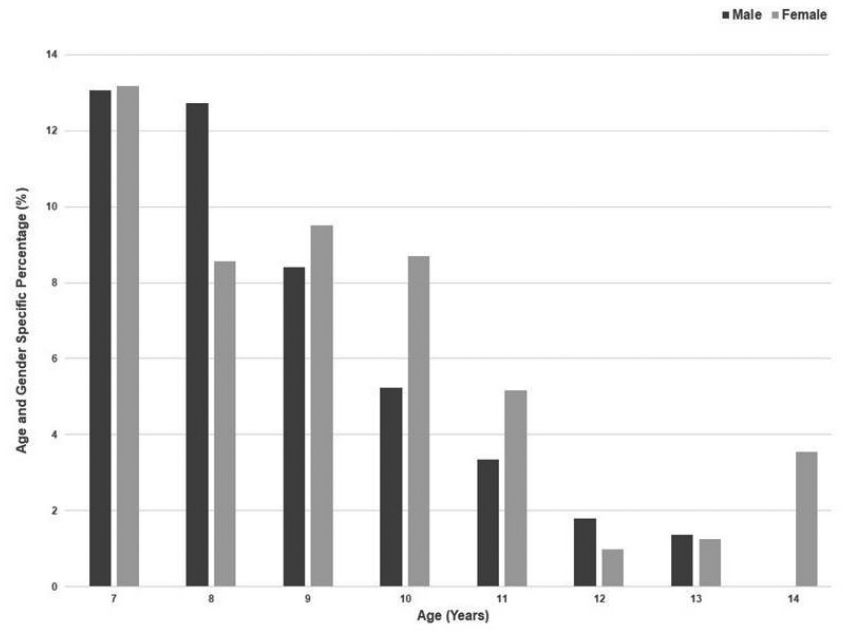

Figure 3. The distributions of voiding dysfunction prevalence according to gender 
Table 2. Familial risk factors for voiding dysfunction

\begin{tabular}{|c|c|c|c|c|c|}
\hline & & $\begin{array}{l}\text { DVSS }<9 \\
\%,(n)\end{array}$ & $\begin{array}{l}\text { DVSS } \geq 9 \\
\%,(n)\end{array}$ & $\begin{array}{l}\text { Total } \\
\%, \text { (n) }\end{array}$ & p value \\
\hline \multicolumn{6}{|c|}{ Mothers' education level } \\
\hline & No education & $0.7(19)$ & $1.5(3)$ & $0.7(22)$ & \multirow{5}{*}{0.140} \\
\hline & Elementary school & $69.5(1957)$ & $68.8(137)$ & $69.5(2094)$ & \\
\hline & Junior high school & $9.4(264)$ & $11.1(22)$ & $9.5(286)$ & \\
\hline & High school & 12.4 (349) & $14.6(29)$ & 12.5 (378) & \\
\hline & University & $8.1(227)$ & $4.0(8)$ & $7.8(235)$ & \\
\hline \multicolumn{6}{|c|}{ Number of siblings } \\
\hline & 0 & $7.6(214)$ & $9.5(19)$ & $7.7(233)$ & \multirow{4}{*}{0.040} \\
\hline & 1 & $43.6(1227)$ & $51.3(102)$ & 44.1 (1329) & \\
\hline & 2 & $32.8(925)$ & $23.6(47)$ & $32.2(972)$ & \\
\hline & $>3$ & $16.0(450)$ & $15.6(31)$ & $16.0(481)$ & \\
\hline \multicolumn{6}{|c|}{ Family income } \\
\hline & Low & $13.1(368)$ & $20.6(41)$ & $13.5(409)$ & \multirow{3}{*}{0.006} \\
\hline & Medium & 83.1 (2339) & $77.4(154)$ & $82.7(2493)$ & \\
\hline & High & 3.9 (109) & $2.0(4)$ & 3.7 (113) & \\
\hline \multicolumn{2}{|l|}{ Total } & $100.0(2816)$ & $100.0(199)$ & $100.0(3015)$ & NA \\
\hline
\end{tabular}

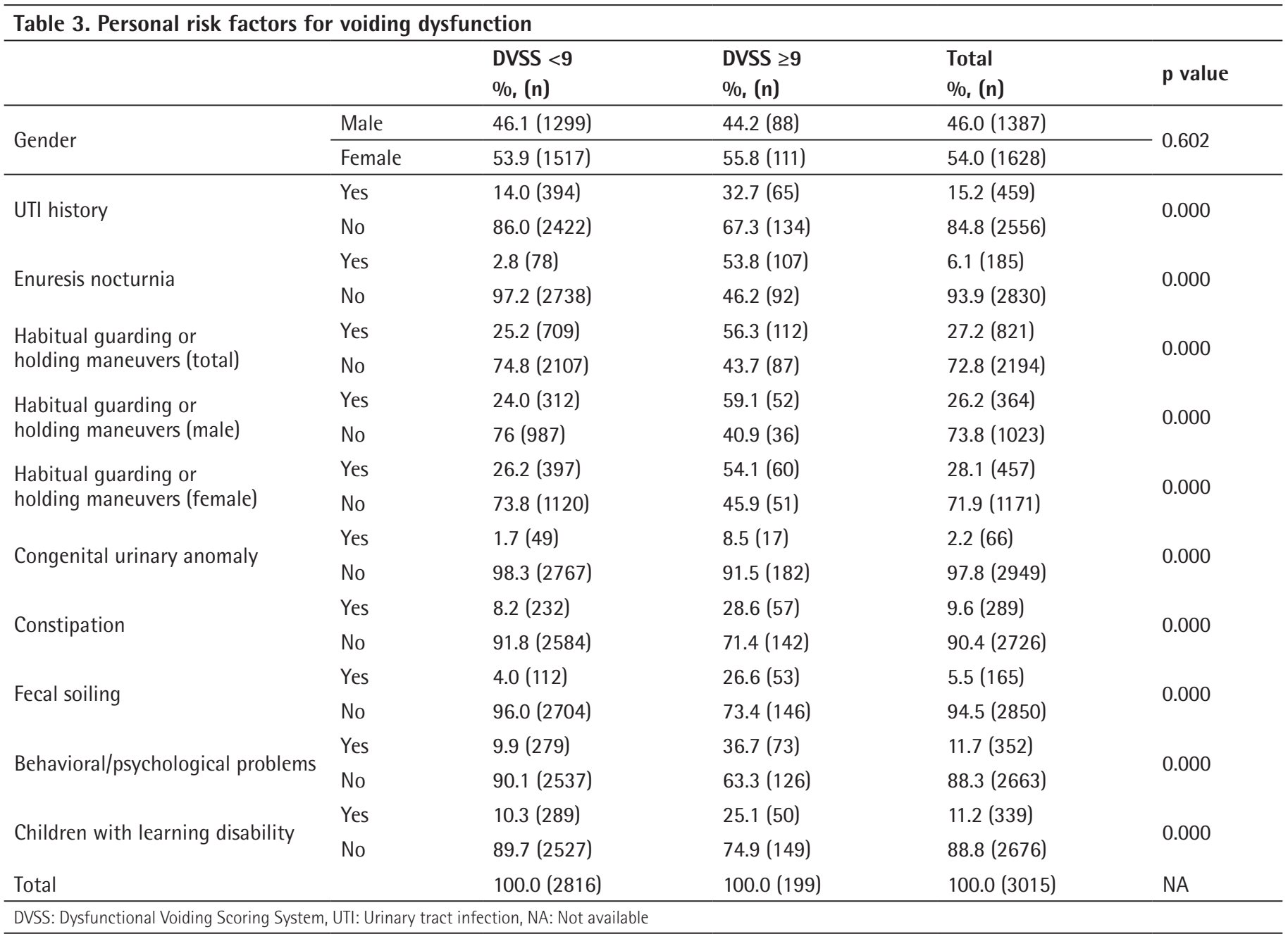


urinary anomaly had a significantly high VD rate (25.8\%), and children with any behavioral or psychological problem $(20.7 \%)$ or learning disability $(14.7 \%)$ had significantly high VD compared with children without such problems (Table 3). Family income and VD were inversely correlated, and children from low-income families had significantly higher VD rates than those from middle- $(p=0.0039)$ and high-income $(p=0.030)$ families (Table 2).

Univariate regression analysis did not reveal any statistically significant factor contributing to VD. However, multivariate analysis revealed a significant difference between VD-positive and -negative children when regarded as jointly on the variables of age and sibling number; Wilk's $\Lambda=0.974, F(2,3045)=40.2$, $p=0.000$, partial $\eta^{2}=0.026$. A separate ANOVA was performed for each dependent variable, with each ANOVA assessed at an alpha level of 0.025. A significant difference was found between VD-positive and -negative children regarding age, $F$ $(1,3046)=80.5, p=0.000$, partial $\eta^{2}=0.026$, with VD-negative patients $(M=10.3)$ scoring lower than VD-positive patients $(M=8.9)$. No significant difference was found between VD-positive and -negative children regarding sibling number, $F$ $(1,3046)=3.8, p=0.051$, partial $\eta^{2}=0.001$.

\section{Discussion}

In our study, the response rate was $67.5 \%$, which was significantly lower than that in studies by Yüksel et al. (15) (86\%) and Bolat et al. (16) (91.9\%). Incompletely answered questionnaires were not assessed, acknowledging that socioeconomic levels may be a factor for not completing questionnaires.

The overall frequency of VD was 6.6\% in primary school children, compared with $9.3 \%$ in the study by Yüksel et al. (15), which was the first reported study evaluating VD with the DVSS questionnaire in an epidemiologic setting in an Anatolian city. Vaz et al. (17) reported a frequency of $21.8 \%$ for VD with a modified DVSS questionnaire in 739 healthy school-age Brazilian children. The population in both studies was younger than the population in our study, and the high rate of VD may be associated with rather low socioeconomic levels. However, our study population was urban.

The prevalence of daytime $\mathrm{UI}$ in children has been reported to be $4.4 \%$ to $19.2 \%$ and $2.1 \%$ to $6.3 \%$ in different European and Asian countries, respectively $(18,19,20,21,22)$. Previous studies have reported prevalence rates between $0.5 \%$ and $8 \%$ in different Turkish cities $(16,23,24,25,26,27)$. In our study, the overall daytime UI prevalence was $6.1 \%$, which was in accordance with the overall NE rate and similar to the results of previous studies. However, most of these studies did not use a validated symptom score system, except for the study by Bolat et al. (16).
Mota et al. (28) reported a VD rate of $24.2 \%$ by using the scoring system of Farhat et al. (12)., Chung et al. (29) reported a VD rate of $46.4 \%$ with a different survey. Yüksel et al. (15) reported that if responders answered only the first question "Does your child have UI during daytime?" as a description of VD in the DVSS questionnaire, the VD rate was 25.4\%. The authors concluded that only one question was sometimes related to an overestimation of frequency. By contrast, in our study, the frequency of VD was nearly the same. For previous studies reporting higher rates, the questionnaires may not have been validated in their country or region.

In this study, no difference in VD was found in the children with regard to age, gender, fluid intake, school type (government and private), or parents' overall education level. Yüksel et al. (15) reported that the prevalence of VD was significantly higher in girls than that in boys only in the age group of 12 to 15 years; in our study, girls had a higher frequency of VD than boys did but this difference was not statistically significant (Figure 3).

In our study, overall education level of the parents did not affect VD rates, but in the subgroup analysis, children of university graduate mothers had statistically lower VD rates than children of non-university graduate mothers $(p<0.05)$. This difference was obvious in the study by Yüksel et al. (15). This difference may be related to the mothers' ability to teach or perform voiding training and mothers' close relationship with children for positive outcomes of VD. Another study reported that the degree of parental education level was inversely correlated with the prevalence of VD (29). Another study reported no statistically significant difference in parental education and VD in children (19).

Many reports have emphasized the association between NE and having more siblings but the association between VD and having more siblings has been considered less frequently $(30,31)$. A study from Turkiye reported that risk factors for VD were having four or more siblings and having two or more persons per bedroom (15). Although we found a statistically significant difference in the overall number of siblings $(p<0.05)$, the difference was not significant in the subgroup analysis.

In our study, the prevalence of VD was higher in children from low-income families than in those from middle- $(p<0.01)$ and high-income families $(p<0.05)$, in agreement with previous studies that evaluated NE and VD $(10,16,32)$. Parents of with high income mostly had a high education level, therefore, this could be an advantage for voiding training and supporting children.

The total frequency of UTI history was $15 \%$ in this study. The children with a history of UTI had a significantly higher prevalence of VD than children without $(p<0.01)$. Although we could not prove this association by using an objective tool or 
test, such as urine culture, in our questionnaire, the previous studies have supported the association between VD and UTI $(15,33)$.

According to previous studies, voiding positions and habits affect the voiding functions in children, especially in girls $(34,35)$. In our study, children who had abnormal voiding positions had a higher prevalence of VD $(p<0.01)$ than those who did not. We only asked parents about the existence of abnormal voiding positions, but a previous study used some pictures of abnormal voiding position to better explain the question (15). This approach might be more beneficial for patient understanding.

Constipation and bowel distension may affect the bladder and cause detrusor hyperactivity and UI (36). In our study, the prevalence of constipation and fecal soiling was significantly higher in children with VD. Many studies have reported higher prevalence rates of $\mathrm{UI}$ in children with constipation $(15,16,17,21,37,38)$. In our study, as per univariate regression analysis, constipation was not a significant contributing factor.

Our study results showed that the prevalence of behavioral or psychological problems and learning disabilities were significantly higher in children with VD, which was also reported in previous studies $(39,40)$. Particularly, inattentive presentation of attention-deficit hyperactivity disorder was demonstrated in children with monosymptomatic NE and nocturnal polyuria. According to teachers, the frequency of urination and a small voided volume might cause more attention problems and a high number of nights with nocturnal polyuria correlated with behavioral problems (40). Treatment of VD or monosymptomatic NE could have positive effects on taking care of behavioral or psychological problems and learning disabilities in children.

According to our study results, children with VD or NE did not seek any treatment or medical counseling before the study. Some myths about the treatment of NE in Anatolia may be a cause for parents' ignorance of VD and NE.

\section{Study Limitations}

Our study had some limitations. The questionnaires were not completed in an interview. We did not enquire about parents' voiding habits during their childhood, so we could not investigate the association between VD in children and VD in parents' childhood. In addition, we could not confirm the diagnosis of VD obtained from our questionnaire and the DVSS questionnaire by accurate clinical evaluation. Finally, we gave cursory information to teachers about VD and NE in children to guide children with VD and NE.

\section{Conclusion}

Our study shows comparable results of the prevalence of VD and $\mathrm{NE}$ in primary school children in an Anatolian city by using the
DVSS questionnaire. VD has a high incidence in early childhood but children can spontaneously recover with age. However children who have any behavioral or psychological problems and learning disabilities have significantly higher VD rates.

\section{Ethics}

Ethics Committee Approval: The permission from the City Directorate of National Education and National Health was obtained.

Informed Consent: Parental consent from the City Directorate of National Education and National Health was obtained.

Peer-review: Externally peer-reviewed.

\section{Authorship Contributions}

Surgical and Medical Practices: H.H.T., Concept: H.H.T., Y.T., C.A., Design: H.H.T., C.A., Data Collection or Processing: H.H.T., E.T., Y.T., Analysis or Interpretation: H.H.T., Y.T., Literature Search: H.H.T., Y.T., Writing: H.H.T., F.Ş., T.T.

Conflict of Interest: No conflict of interest was declared by the authors.

Financial Disclosure: The authors declared that this study received no financial support.

\section{References}

1. Ramakrishnan K. Evaluation and treatment of enuresis. Am Fam Physician 2008;78:489-496

2. Neveus T, von Gontard A, Hoebeke P, Hjalmas K, Bauer S, Bower W, Jorgensen TM, Rittig S, Walle JV, Yeung CK, Djurhuus JC. The standardization of terminology of lower urinary tract function in children and adolescents: report from the Standardisation Committee of the International Children's Continence Society. J Urol 2006;176:314-324.

3. Akbal C, Genc Y, Burgu B, Ozden E, Tekgul S. Dysfunctional voiding and incontinence scoring system: quantitative evaluation of incontinence symptoms in pediatric population. J Urol 2005;173:969-973.

4. Schultz-Lampel D, Steuber C, Hoyer PF, Bachmann CJ, Marschall-Kehrel D, Bachmann H. Urinary incontinence in children. Dtsch Arztebl Int $2011 ; 108: 613-620$

5. Nevéus T, von Gontard A, Hoebeke P, Hjälmås K, Bauer S, Bower W, Jørgensen TM, Rittig S, Walle JV, Yeung CK, Djurhuus JC. The standardization of terminology of lower urinary tract function in children and adolescents: report from the Standardisation Committee of the International Children's Continence Society. J Urol 2006;176:314-324.

6. Franco I. Overactive bladder in children. Part 2: Management. J Urol 2007;178:769-774.

7. Carman KB, Ceran O, Kaya C, Nuhoglu C, Karaman MI. Nocturnal enuresis in Turkey: prevalence and accompanying factors in different socioeconomic environments. Urol Int 2008;80:362-366.

8. Ozkan S, Durukan E, Iseri E, Gürocak S, Maral I, Ali Bumin M. Prevalence and risk factors of monosymptomatic nocturnal enuresis in Turkish children. Indian J Urol 2010;26:200-205.

9. Sarici H, Telli O, Ozgur BC, Demirbas A, Ozgur S, Karagoz MA. Prevalence of nocturnal enuresis and its influence on quality of life in school-aged children. J Pediatr Urol 2016;12:159. 
10. Doganer YC, Aydogan U, Ongel K, Sari O, Koc B, Saglam K. The Prevalence and Sociodemographic Risk Factors of Enuresis Nocturna among Elementary School-age Children. J Family Med Prim Care 2015;4:39-44.

11. Sureshkumar $\mathrm{P}$, Caldwell PH, Craig JC. Diagnosing daytime bladder symptoms in children with nocturnal enuresis: a comparison of brief parental questionnaire with in-depth, physician-elicited, assessment. J Paediatr Child Health 2010;46:636-641.

12. Farhat W, Bagli DJ, Capolicchio G, O'Reilly S, Merguerian PA, Khoury A, McLorie GA. The dysfunctional voiding scoring system: quantitative standardization of dysfunctional voiding symptoms in children. J Urol 2000;164:1011-1015.

13. van Gool JD, Hjalmas K, Tamminen-Mobius T, Olbing H. Historical clues to the complex of dysfunctional voiding, urinary tract infection and vesicoureteral reflux. The International Reflux Study in Children. J Urol 1992;148:1699-1702.

14. Akbal C, Sahan A, Sener TE, Sahin B, Tinay I, Tarcan T, Simsek F. Diagnostic value of the pediatric lower urinary tract symptom score in children with overactive bladder. World J Urol 2014;32:201-208.

15. Yüksel S, Yurdakul AÇ, Zencir M, Çördük N. Evaluation of lower urinary tract dysfunction in Turkish primary schoolchildren: an epidemiological study. J Pediatr Urol 2014;10:1181-1186.

16. Bolat D, Acar IC, Zumrutbas AE, Eskicorapci S, Sancak EB, Zencir M, Turan T, Sinik Z. Prevalence of daytime urinary incontinence and related risk factors in primary school children in Turkey. Korean J Urol 2014;55:213-218.

17. Vaz GT, Vasconcelos MM, Oliveira EA, Ferreira AL, Magalhaes $P G$, Silva FM, Lima EM. Prevalence of lower urinary tract symptoms in school-age children. Pediatr Nephrol 2012;27:597-603.

18. Bakker E, van Sprundel M, van der Auwera JC, van Gool JD, Wyndaele JJ. Voiding habits and wetting in a population of 4,332 Belgian schoolchildren aged between 10 and 14 years. Scand J Urol Nephrol 2002;36:354-362.

19. Sureshkumar $P$, Craig JC, Roy LP, Knight JF. Daytime urinary incontinence in primary school children: a population-based survey. J Pediatr 2000;137:814818.

20. Bower $W F$, Moore $K H$, Shepherd RB, Adams RD. The epidemiology of childhood enuresis in Australia. Br J Urol 1996;78:602-606.

21. Kajiwara $M$, Inoue $K$, Usui $A$, Kurihara $M$, Usui T. The micturition habits and prevalence of daytime urinary incontinence in Japanese primary school children. J Urol 2004;171:403-407.

22. Lee SD, Sohn DW, Lee JZ, Park NC, Chung MK. An epidemiological study of enuresis in Korean children. BJU Int 2000;85:869-873.

23. Toktamis $A$, Demirel $Y$, Ozkan $K U$, Garipardiç $M$, Gözükücük $A$, Nur N. Prevalence and associated factors of day wetting and combined day and night wetting. Urol Int 2008;81:54-59.

24. Serel TA, Akhan G, Koyuncuoglu HR, Oztürk A, Doğruer K, Unal S, Celik K. Epidemiology of enuresis in Turkish children. Scand J Urol Nephrol 1997;31:537-539.

25. Oge 0, Kocak I, Gemalmaz H. Enuresis: point prevalence and associated factors among Turkish children. Turk J Pediatr 2001;43:38-43.
26. Ozkan KU, Garipardic M, Toktamis A, Karabiber H, Sahinkanat T. Enuresis prevalence and accompanying factors in schoolchildren: a questionnaire study from southeast Anatolia. Urol Int 2004;73:149-155.

27. Uğuralp $S$, Karaoğlu L, Karaman A, Demircan M, Yakinci C. Frequency of enuresis, constipation and enuresis association with constipation in a group of school children aged 5-9 years in Malatya, Turkey. Turk J Med Sci 2003;33:315-320.

28. Mota DM, Victora CG, Hallal PC. [Investigation of voiding dysfunction in a population-based sample of children aged 3 to nine years]. J Pediatr (Rio J) 2005;81:225-232.

29. Chung JM, Lee SD, Kang DI, Kwon DD, Kim KS, Kim SY, Kim HG, Moon du G, Park KH, Park YH, Pai KS, Suh HJ, Lee JW, Cho WY, Ha TS, Han SW; Korean Enuresis Association. An epidemiologic study of voiding and bowel habits in Korean children: a nationwide multicenter study. Urology 2010;76:215-219.

30. Ozden C, Ozdal OL, Altinova S, Oguzulgen I, Urgancioglu G, Memis A. Prevalence and associated factors of enuresis in Turkish children. Int Braz J Urol 2007;33:216-222.

31. Gür E, Turhan $P$, Can $G$, Akkus $S$, Sever L, Guzelöz $S$, Cifcili $S$, Arvas A. Enuresis: prevalence, risk factors and urinary pathology among school children in Istanbul, Turkey. Pediatr Int 2004;46:58-63.

32. Dirim A, Aygün YC, Bilgilisoy UT, Durukan E. Prevalence and associated factors of daytime lower urinary tract dysfunction in students of two primary schools of turkey with different socioeconomic status. Turkiye Klinikleri J Urol 2011;2:1-6.

33. Afshar K, Mirbagheri A, Scott H, MacNeily AE. Development of a symptom score for dysfunctional elimination syndrome. J Urol 2009;182(4 Suppl):1939-1943.

34. Uluocak N, Oktar T, Acar O, Incesu O, Ziylan O, Erkorkmaz U. Positional changes in voiding dynamics of children with non-neurogenic bladder dysfunction. Urology 2008;72:530-534.

35. Furtado PS, Lordelo $\mathrm{P}$, Minas $\mathrm{D}$, Menezes J, Veiga $\mathrm{ML}$, Barroso U Jr. The influence of positioning in urination: an electromyographic and uroflowmetric evaluation. J Pediatr Urol 2014;10:1070-1075.

36. Koff $S A$, Wagner $\Pi$, Jayanthi VR. The relationship among dysfunctional elimination syndromes, primary vesicoureteral reflux and urinary tract infections in children. J Urol 1998;160:1019-1022.

37. Söderstrom $U$, Hoelcke $M$, Alenius $L$, Söderling AC, Hjern A. Urinary and faecal incontinence: a population-based study. Acta Paediatr 2004;93:386389.

38. Loening-Baucke V. Prevalence rates for constipation and faecal and urinary incontinence. Arch Dis Child 2007;92:486-489.

39. Franco I. Neuropsychiatric disorders and voiding problems in children. Curr Urol Rep 2011;12:158-165.

40. Van Herzeele C, Dhondt K, Roels SP, Raes A, Groen LA, Hoebeke P, Walle JV. Neuropsychological functioning related to specific characteristics of nocturnal enuresis. J Pediatr Urol 2015;11:208. 